\title{
Sustainability in the Cocoa Production Chain in Côte d'Ivoire: Schooling, Women Empowerment and Household Living Condition
}

\author{
Kouadio Kouassi Hugues \\ African Center of Excellence in Statistics and Applied Economics, ENSEA, Abidjan, Côte d'Ivoire \\ Email: hkouadio@ensea.ed.ci
}

How to cite this paper: Hugues, K. K. (2020). Sustainability in the Cocoa Production Chain in Côte d'Ivoire: Schooling, Women Empowerment and Household Living Condition. Open Journal of Social Sciences, 8, 191-208.

https://doi.org/10.4236/jss.2020.88017

Received: July 9, 2020

Accepted: August 18, 2020

Published: August 21, 2020

Copyright $\odot 2020$ by author(s) and Scientific Research Publishing Inc. This work is licensed under the Creative Commons Attribution International License (CC BY 4.0).

http://creativecommons.org/licenses/by/4.0/

\begin{abstract}
With a view to ensuring sustainability in the cocoa production chain in Côte d'Ivoire, various organizations including cocoa companies are intervening, through NGOs, in cocoa production areas to improve women empowerment; improve education, and vocational training of young people with the ultimate objective of improving the living conditions of cocoa producing populations. What is the status of the associated indicators? The study attempted to evaluate the status of the associated indicators regarding living condition of cocoa famers through education, women empowerment and vocational training. Base on a combination of probability sampling and qualitative interviews, 30 communities, 678 children and 360 women were selected considering beneficiaries and non-beneficiaries of support and according to the categories of eligible populations and leading to 2291 interviews conducted overall, and an overall response rate of $92 \%$. Different indicators were considered to measure literacy and numeracy skills; multidimensional poverty; and women empowerment. Quantitative methods were used notably ANCOVA and multivariate data analysis. The main findings are as follows: 1) Living conditions in the communities are closer to the national situation. Monetary poverty rate is $42 \%$, with a greater extent among large households; 2) Children's French and Math skills are average and those of adult women are low; 3) There is also child labor. In these communities, three out of five children devote themselves entirely to their studies while one child out of six is at work; 4) Women are involved in production activities, particularly cocoa cultivation, food crops and IGAs. However, women empowerment is not relevant.
\end{abstract}

\section{Keywords}

Cocoa, Education, Women Empowerment, Poverty, Living Conditions 


\section{Introduction}

Various reports on education, including the State Report on the National Education System (Gouvernement de Côte d'Ivoire et al., 2016; PASEC, 2016), show, in addition to the need to improve the education system as a whole, that the real challenges of universal basic education for Côte d'Ivoire lie in its capacity to target and reach more children in rural areas, certain administrative regions such as North, North-West and Centre-West, and poor families.

Therefore, the situation of women is a challenge. Indeed, according to the African Development Bank's African Gender Equality report (AfDB, 2015) on women empowerment, the gender equality index is low in Côte d'Ivoire compared to all African countries. This inequality between men and women in Côte d'Ivoire is more significant and decreasingly significant in the "economic opportunity", "laws and institutions", and "human development" dimensions.

These challenges of both basic education and the situation of women in Côte d'Ivoire are certainly more pronounced in cocoa-producing communities, for which Côte d'Ivoire is the world's leading producer with a share of some $40 \%$ of the global cocoa volume. The general level of education in the majority of farming families is inadequate. On the whole the literacy rate of the population in Côte d'Ivoire is only just over 40 percent, despite the fact that school attendance is obligatory. A lack of financial resources and poor infrastructure makes it impossible for many children and young people to attend school. In many villages in Côte d'Ivoire there is quite simply no school and there is no one in the immediate vicinity. And the existence of a school does not by a long way mean that there are also teachers or teaching materials there.

It is therefore in this context that companies in the cocoa sector, based on existing diagnoses (Banque Mondiale, 2011; Ministère de l'Éducation Nationale, 2014a, 2014b, 2014c; Aos et al., 2004; Anderson, 1988) and in relation with civil society organizations, undertake to ensure sustainable development in cocoa-producing areas through quality education with the aim of improving populations living conditions, young people and women's education on the one hand, and combating child labour in Côte d'Ivoire on the other hand.

This is a different approach, but complementary to the traditional sustainable development initiatives commonly adopted by NGOs, chocolate companies and various stakeholders in the sector. Indeed, sustainability in cocoa has received a lot of attention in the recent years in order to bring about greater economic wealth and fairness, social justice in the producing countries, as well as social responsibility and ecological sustainability along the global value-added chain. The focus is biased toward promotion of socially-responsible and environmentally-compatible cocoa production (sustainability standards, programs for the development of capacities, and in particular projects to tackle exploitative child labour).

The sustainable development initiative that is the subject of our study focuses on promoting education and gender as a factor in the sustainability of cocoa-producing 
communities. Planned activities include the provision of quality education in cocoa-producing communities. These activities are organized around three main themes: education, women empowerment and child labour. In particular, the intervention consists of organizing 1) support courses for children at risk of school failure and those outside the school system and basic reading courses; 2) vocational training for young people; and 3) basic courses in literacy, numeracy and functional finance for women ( $>15$ years old).

The main objective of the study is to build indicators characterizing the situation of these communities according to the dimensions of sustainable development considered and the interventions planned by the stakeholders of the initiative. To this end, we have collected specific data. The baseline situation of the target populations was determined on the basis of a probability sampling survey and qualitative interviews with beneficiary and non-beneficiary populations. The sample size was determined, with 95\% confidence level precision and change scenarios, based on the following information: total size of beneficiaries, average score obtained in the literacy and numeracy tests in the PASEC (2016) study in Côte d'Ivoire.

The main results are as follows: 1) living conditions in the communities are closer to the national situation. Monetary poverty rate is $42 \%$, with a higher magnitude in large households; 2) children's French and Math skills are average and those of adult women are low; 3 ) the phenomenon of child labour is very present, with a low magnitude, in the areas studied. In these communities, three out of five children devote themselves entirely to their studies while one child out of six works; 4) the majority of women participate in production activities, particularly cocoa growing, food crops and income-generating activities. However, women empowerment is not relevant.

The rest of the paper is structured as follows: Section 2 describes the community under study, the chocolate companies' support for sustainable community development. Section 3 presents research method comprising sampling, data collection strategy and the main calculated indicators. Section 4 presents results of the study while Section 5 is devoted to the conclusion.

\section{Communities and Support Received from Cocoa Sector Companies}

This section gives an overview of cocoa production in Côte d'Ivoire, challenges faced by the sector and specific support provided to improve living condition of cocoa-producing communities in the context of our study, the TRECC Program (Transforming Education in Cocoa Communities).

About $40 \%$ of cocoa produced worldwide comes from Côte d'Ivoire (ICCO, 2017) and the country has remained the largest producing country worldwide. Cocoa forms $15 \%$ of Ivorian GDP, which is $40 \%$ of the nation's export earnings (Verter, 2016). Ivorian farmers produced a record harvest of 1,690,000 tonnes of cocoa in 2016/2017, attributed to the favourable weather. There were between 
800,000 and 1,200,000 smallholder cocoa farmers, and 3000 registered farmer organisations in 2016 (Hütz-Adams, Huber et al., 2016).

The cocoa sector continues to face a number of deeply embedded, interrelated challenges, including old trees with low tree productivity; low farmer and worker incomes; pests and diseases such as swollen shoot virus, political instability; persistent poor labour and working conditions; challenges to scaling up service delivery to farmers; negative environmental impacts, such as deforestation, soil degradation and pollution; and a tight relationship between supply and demand in the face of growing demand with long-term cyclical recession and expansion booms affecting global market and farmgate prices (Ruf \& Siswoputranto, 1995; Nkamleu et al., 2010; Matissek et al., 2012; Bitty et al., 2015; Wilson et al., 2016; International Cocoa Inititative, 2017; Muilerman \& Vellema, 2017; Ingram et al., 2017). Following the global trend in the cocoa value chain (Ingram et al., 2018), in Côte d'Ivoire, an increasing number of initiatives have been developed and implemented since 2012 (Ingram et al., 2014), increasingly by combinations of national and international public, private, civil society, NGO and research organisations.

In this context chocolate companies have undertaken to develop a program aimed at accelerating sustainability in the cocoa production chain in Côte d'Ivoire and improving the living conditions of cocoa farmers, with a strong emphasis on increasing the productivity and income of farmers. In particular, support implemented by NGOs focuses on education, women empowerment and child labour. Operationalization is done through 1) support courses for children at risk of school failure and those outside the school system and basic reading courses; 2) vocational training for out-of-school youth; and 3) the organization of basic reading, numeracy and functional finance courses for women.

Support classes for children at risk of school failure and those outside the school system and basic reading classes are organized for two target populations: 1) in-school children at risk of failure, 2) and children outside the system (out-of-school children). This activity focuses on improving literacy and numeracy skills of both categories of populations. The first category receives support courses from rural educators to improve retention in the formal system. The second category also receives support courses with a view to their integration or reintegration into the formal system. It is expected, on the one hand, that literacy and numeracy skills will be improved for the beneficiaries and, on the other hand, that the support activity for children at risk of school failure will contribute to increasing the success rate among children at risk of failure in the communities where projects are implemented. Also, support for children outside the system with a view to their integration should lead to the integration of children into the school system.

Vocational training for young people aims to give them the skills to either continue the businesses in which they are involved or to start new ones. This should ultimately lead to an improvement in the activity rate of young people 
who have completed the training.

The organization of basic courses in literacy, numeracy and functional finance is intended for women members of Economic Interest Groups (EIGs), which should enable them to communicate better (reading, writing and numeracy) and better manage their income-generating activities. A better management of their activities as well as new skills should enable women to be more assertive in decision-making concerning their activities, managing their income, speaking out and participating in organizations and groups. All these aspects should ultimately contribute to increasing women's level of influence in decision-making within the household and in the community.

The intervention zone is made up of the cocoa production zones in Côte d'Ivoire from East to West of Côte d'Ivoire, i.e. all the cocoa loops (Kouadio \& Desdoigts, 2012; Bros et al., 2019). The population is made up of migrants and indigenous people. Migrants fall into two categories: migrants internal to Côte d'Ivoire leaving other areas, particularly the centre, and non-Ivorian populations who have come to settle in order to take advantage of the land suitable for cocoa cultivation (Babo, 2010). The majority of the population is young with a sex ratio of 104.

\section{Research Method}

\subsection{Sample and Data Collection Strategy}

The measurement of these interventions effects is obtained from indicators whose estimates are calculated after conducting a survey of the beneficiary and non-beneficiary populations. The study sample is made up of nearly $30 \mathrm{com}-$ munities selected from five major geographic areas. When a community is selected for an activity, thirty (30) beneficiaries are selected within it.

- Sample

The sample size was determined, with $95 \%$ confidence level precision and change scenarios, based on the following information: the total size of the beneficiaries, the average score obtained in the literacy and numeracy tests in PASEC study (2016) in Côte d'Ivoire, and assumptions about the Minimum Detectable Effects (MDE). The power of the test was set at $80 \%$ and the hypothesis of an equitable distribution between the beneficiaries and the control group was made. Thus, this scenario led to a total size of 460 for children and 271 for women (cf. Figure 1 \& Figure 2).

These sizes are designed to detect improvements of $10 \%$ in the variable of interest for children and $20 \%$ for women. In the women population, the determination of $10 \%$ of change leads to a size of 306 . Taking into account the possibility of attrition and non-response, the sample size is increased by approximately $10 \%$. Also, the possibilities of total non-adherence lead to the hypothesis of a participation rate of $80 \%$, which finally results in a sample size of 678 for children and 360 for women (cf. Table 1).

Data were collected from beneficiaries from a sample of communities using a 


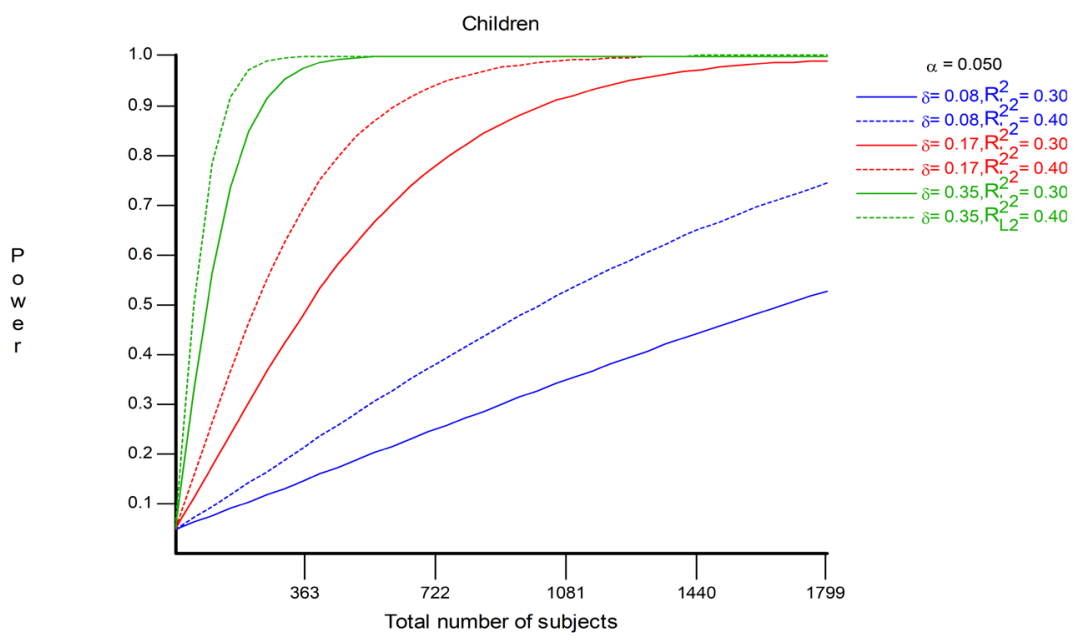

Figure 1. Determination of the sample size of children under different scenarios with an accuracy for $\alpha=0.05$ and different values of the minimum detectable difference $(\delta)$ the square of the standard deviation $\left(\mathrm{R}^{2}\right)$.

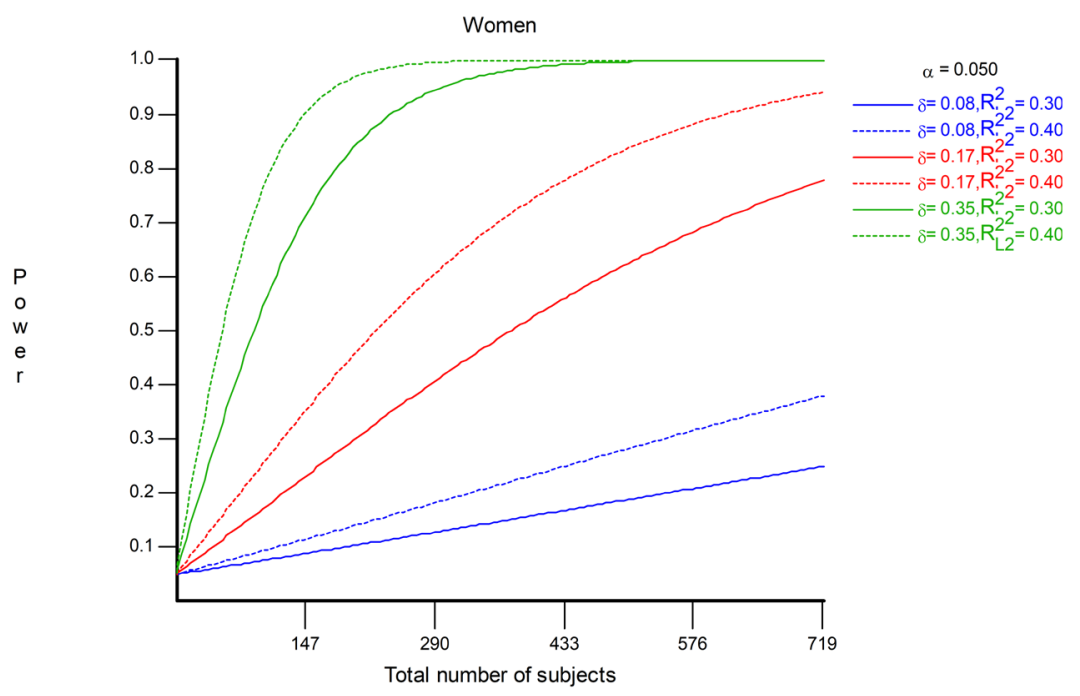

Figure 2. Determination of the sample size of women under different scenarios with an accuracy for $\alpha=0.05$ and different values of the minimum detectable difference $(\delta)$ the square of the standard deviation $\left(\mathrm{R}^{2}\right)$.

Table 1. Sample size by intervention.

\begin{tabular}{lll}
\hline & Households \\
\cline { 3 - 3 } Intervention & Objective & Achieved \\
\hline $\begin{array}{l}\text { Training of rural educators to provide support courses to children (6 - 9 } \\
\text { years) at risk of failure or children outside the system (9 - 13 years) to } \\
\text { reintegrate them }\end{array}$ & 678 & 620 \\
$\begin{array}{l}\text { Basic courses in literacy, numeracy and functional finance for women } \\
\text { (>14 years old) participating in EIGs (Economic Interest Groupings) }\end{array}$ & 360 & 359 \\
$\begin{array}{l}\text { Vocational training courses for young people (14 - 17 years) outside the } \\
\text { school system }\end{array}$ & 20 & 49 \\
Poverty and household quality of life & 539 & 411 \\
\hline
\end{tabular}

Source: ENSEA, TRECC Survey data. 
stratified survey. The stratification is done according to locality and according to the activities implemented. The beneficiaries subject to data collection were randomly selected from the list of beneficiaries. Non-beneficiaries were selected randomly to serve as a control of the intervention. In each of the non-beneficiary communities, data collection began with a census in randomly selected blocks. This operation made it possible to identify households in which there were children at risk of failure, children outside the education system, and households with female women members of EIGs.

\section{- Data collection}

Data collection took place over a period of one month from 08 December 2016 to 03 January 2017. It began with a pilot phase with all the statistical units designated for this study. This pilot phase involved 09 children of first- and second-year in primary school (CP1 and CP2) whose ages ranged from 6 to 8 years, their respective households and the head of their school, 03 young people over 17 years old who had dropped out of school, about ten women in agricultural activity or not and their head of household. After this pilot phase, a debriefing was held to share experiences. A total of five teams were formed for the actual field phase: three teams of 04 agents, on the one hand, and two teams of 05 agents, on the other hand. They had a target of approximately 2500 interviews divided into categories. At the end of the collection, a total of 2291 interviews were conducted, which corresponds approximately to an overall response rate of $92 \%$.

\subsection{Indicators}

Three main indicators were calculated as a result of data collection. These are indicators measuring literacy and numeracy skills; poverty indicators; and indicators of women empowerment.

A score was calculated at the end of the proposed test in Mathematics and French. The items used to calculate this score were subjected to Cronbach's alpha (Cronbach, 1951 and Dickes et al., 1994, cf. Annex) for the measurement of an ability and to a difficulty test (PASEC, 2016) to rule out questions that were too easy or too difficult for the analysis sample (cf. Annex). Poverty is measured by the monetary approach and by a multidimensional approach (cf. Table 2) (Alkire et al., 2015). The monetary approach consisted of collecting information on household members' expenditures and then comparing the amount of expenditures to the national poverty line. Empowerment is the enhancement of people's capacities to make strategic life choices within their households and communities, especially in contexts where this capacity has been limited. Empowerment is measured by an A-WEAI index (cf. Table 3) (Feed the Future, 2017; OPHI, 2012; Sen \& Batliwala, 2000).

Analyses carried out mainly use univariate and multivariate descriptive analysis methods. Regression models have also been used, notably in the implementation of the ancova. Also, to confirm equality, statistical tests (Chi-square test, 
ancova, equal proportion test, etc.) were conducted. Unless otherwise stated, all these tests were conducted at the $5 \%$ threshold.

Table 2. Multidimensional poverty dimension.

\begin{tabular}{|c|c|c|c|}
\hline Dimension & Indicators & Is poor if ... & Weight \\
\hline \multirow{2}{*}{ Education } & Schooling year & $\begin{array}{l}\text { No household member of } 10 \text { years of age or older } \\
\text { has completed } 5 \text { years of education }\end{array}$ & $1 / 6$ \\
\hline & School attendance & $\begin{array}{l}\text { A school-going age child does not go to school } \\
\text { until he or she can complete primary school. }\end{array}$ & $1 / 6$ \\
\hline \multirow[b]{2}{*}{ Health } & Infant mortality & $\begin{array}{l}\text { The household has experienced a child death in } \\
\text { the last } 5 \text { years }\end{array}$ & $1 / 6$ \\
\hline & Nutrition $^{\mathrm{a}}$ & $\begin{array}{l}\text { A child or adult in the household, for } \\
\text { whom nutritional information is available, is } \\
\text { malnourished }\end{array}$ & $1 / 6$ \\
\hline \multirow{6}{*}{$\begin{array}{l}\text { Living } \\
\text { conditions }\end{array}$} & Electricity & Household does not have running electricity & $1 / 18$ \\
\hline & Sanitation & $\begin{array}{l}\text { Household sanitation facilities are not adequate } \\
\text { or are used in common with other households }\end{array}$ & $1 / 18$ \\
\hline & Drinking water & $\begin{array}{l}\text { The household does not have access to safe } \\
\text { drinking water or this access is } 30 \text { minutes or } \\
\text { more on foot for a round trip }\end{array}$ & $1 / 18$ \\
\hline & Floor covering & $\begin{array}{l}\text { The floor of the house is made of mud, dung or } \\
\text { sand }\end{array}$ & $1 / 18$ \\
\hline & Cooking energy & $\begin{array}{l}\text { The household uses dung, wood or coal as } \\
\text { cooking fuel }\end{array}$ & $1 / 18$ \\
\hline & Capital goods & $\begin{array}{l}\text { The household does not own more than one of } \\
\text { the following: radio, TV, telephone, bicycle, } \\
\text { motorcycle, refrigerator, and does not have a car } \\
\text { or truck }\end{array}$ & $1 / 18$ \\
\hline
\end{tabular}

${ }^{a}$ This dimension has not been taken into account. Therefore, the weight has been revised and is valid for infant mortality $1 / 3$. Source: ENSEA, TRECC Survey data.

Table 3. Areas, indicators and weights of the Women Empowerment in Agriculture In$\operatorname{dex}(\mathrm{WEAI})$

\begin{tabular}{lll}
\hline Areas & Indicators & Weights \\
\hline Production & Input into agricultural decisions & $1 / 10$ \\
& Empowerment in production & $1 / 10$ \\
& Ownership of assets & $1 / 15$ \\
Resources & Purchases, sales and transfers of assets & $1 / 15$ \\
& Access to and decision on credit & $1 / 15$ \\
Women's control over income & Control over the use of incomes & $1 / 5$ \\
Leadership and individual influence & Joining a group & $1 / 10$ \\
of women in the community & Public speaking & $1 / 10$ \\
Time allocation for women & Workload & $1 / 10$ \\
\end{tabular}

Sources: ENSEA, TRECC Survey data. 


\section{Results and Analysis}

The populations of the communities studied are relatively young, similar to the populations of developing countries, with a sex ratio of 107 . This population is essentially agricultural (92\%) with a relatively low level of education ( $81 \%$ have at most primary education level).

The poverty level of these communities was estimated using both monetary and non-monetary approaches. From a monetary point of view, about $42 \%$ of households in these communities are identified as poor. As for non-monetary poverty, the rate is even higher. In fact, one household out of two is poor in living conditions (cf. Table 4 and Table 5).

As far as children are concerned, beneficiaries and non-beneficiaries perform similarly in both French and Mathematics, with an average score of 52 out of 100 items in French, 39 out of 100 items in Mathematics and 46 out of 100 items on all tests combined (cf. Table 6). Also, the proportion of children below the threshold considered sufficient in French is approximately 35\%, while it is approximately $65 \%$ in Mathematics.

Table 4. Poverty indicators by Household Head $(\mathrm{HH})$ gender and household size.

\begin{tabular}{|c|c|c|c|c|}
\hline & \multicolumn{3}{|c|}{ Poverty Indicators } & \multirow{2}{*}{ Size $(\mathrm{N})$} \\
\hline & $\mathrm{P} 0$ & $\mathrm{P} 1$ & $\mathrm{P} 2$ & \\
\hline \multicolumn{5}{|c|}{ Sex of the Household Head } \\
\hline Male & 0.44 & 0.18 & 0.10 & 594 \\
\hline Female & 0.31 & 0.13 & 0.08 & 104 \\
\hline \multicolumn{5}{|c|}{ Size of the Household } \\
\hline Less than 6 & 0.32 & 0.11 & 0.06 & 300 \\
\hline $6-9$ & 0.47 & 0.21 & 0.12 & 331 \\
\hline More than 10 & 0.53 & 0.24 & 0.14 & 107 \\
\hline
\end{tabular}

Source: ENSEA, TRECC Survey data.

Table 5. Main indicators of the Multidimensional Poverty Indicator (MPI).

\begin{tabular}{cc}
\hline Indicators & As a Whole \\
\hline Non-poverty score (1-IPM) & 0.76 \\
\% of non-poor households (1-H) & 45.90 \\
\% of poor households (H) & 54.09 \\
Average no-privation scores of poor households & 0.53 \\
Average privation scores of poor households (A) & 0.46 \\
$\mathrm{~N}^{\circ}$ Obs. & 699 \\
IPM score & 0.24 \\
\hline
\end{tabular}

Source: ENSEA, TRECC Survey data. 
Table 6. Average score on French and Mathematics tests by beneficiary status and category (children).

\begin{tabular}{|c|c|c|c|c|c|}
\hline \multirow{2}{*}{ Variable } & \multicolumn{5}{|c|}{ Summary statistics } \\
\hline & Obs. & Mean & Std. Dev. & Min & $\operatorname{Max}$ \\
\hline \multicolumn{6}{|c|}{ Bridge Beneficiary } \\
\hline Total score & 35 & 52.40 & 25.16 & 4.87 & 90.24 \\
\hline French & 35 & 55.95 & 27.06 & 8.33 & 95.83 \\
\hline Maths & 35 & 47.39 & 27.66 & 0 & 94.11 \\
\hline \multicolumn{6}{|c|}{ Academic Support Beneficiary } \\
\hline Total score & 202 & 52.51 & 25.06 & 7.31 & 100 \\
\hline French & 202 & 57.12 & 23.98 & 8.33 & 100 \\
\hline Maths & 202 & 46.01 & 30.81 & 0 & 100 \\
\hline \multicolumn{6}{|c|}{ Single Class Beneficiary } \\
\hline Total score & 78 & 32.15 & 23.40 & 2.44 & 97.56 \\
\hline French & 78 & 41.24 & 24.48 & 4.17 & 100 \\
\hline Maths & 78 & 19.31 & 26.78 & 0 & 94.12 \\
\hline \multicolumn{6}{|c|}{ Bridge Non-Beneficiary } \\
\hline Total score & 50 & 45.42 & 24.35 & 7.32 & 97.56 \\
\hline French & 50 & 50.00 & 24.31 & 8.33 & 95.83 \\
\hline Maths & 50 & 38.94 & 28.62 & 0 & 100 \\
\hline \multicolumn{6}{|c|}{ Academic Support Non-Beneficiary } \\
\hline Total score & 159 & 54.82 & 27.37 & 0 & 100 \\
\hline French & 159 & 59.20 & 26.40 & 0 & 100 \\
\hline Maths & 159 & 48.65 & 31.99 & 0 & 100 \\
\hline \multicolumn{6}{|c|}{ Single Class Non-Beneficiary } \\
\hline Total score & 96 & 33.11 & 22.44 & 0 & 92.68 \\
\hline French & 96 & 38.80 & 23.16 & 0 & 91.67 \\
\hline Maths & 96 & 25.06 & 26.71 & 0 & 100 \\
\hline
\end{tabular}

Source: ENSEA, TRECC Survey data.

Concerning women, skills are relatively lower (cf. Table 7). Indeed, adult women passed an average of 29 out of 100 items in French and Mathematics. The communities are therefore characterized by a majority of adult women with a low level in Mathematics and French who coexist with a minority with relatively high performance in French (cf. Figure 3).

The phenomenon of child labour is very present in the areas studied. In the communities studied, three out of five children in the communities studied are fully dedicated to their studies, while one out of six children is fully dedicated to labour. 


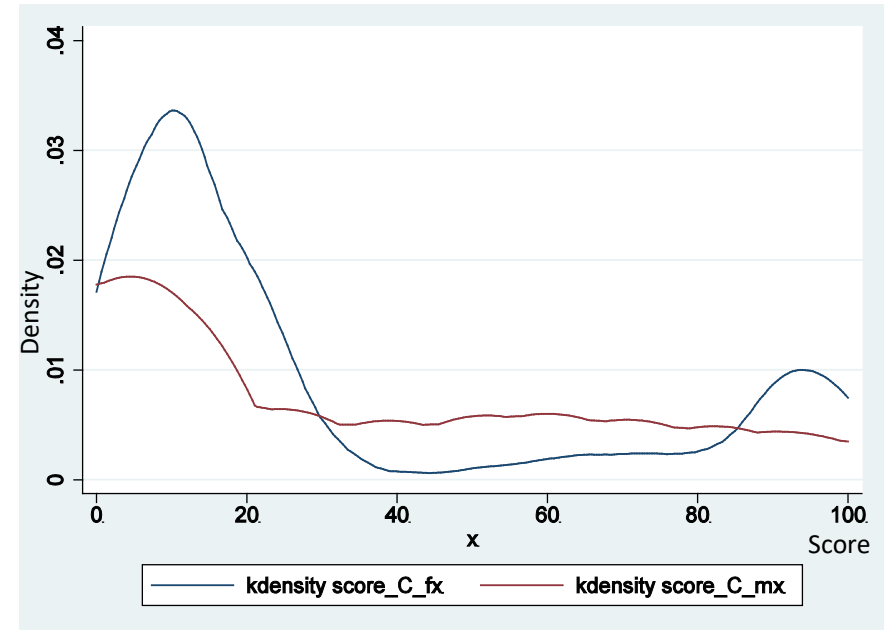

Figure 3. Determination of Women's scores in French and Mathematics. fx (in blue) the density of scores in French; mx (in red) the density of scores in Mathematics.

Table 7. Average score in French and Mathematics tests by status (women).

\begin{tabular}{lccccc}
\hline Variable & Obs. & Mean & Std. Dev. & Min & Max \\
\hline Beneficiary & & & & & \\
Total score & 166 & 25.74 & 30.71 & 0 & 98.41 \\
French & 166 & 26.13 & 31.21 & 0 & 100 \\
Maths & 166 & 23.43 & 31.28 & 0 & 100 \\
Non-Beneficiary & & & & & \\
Total score & 181 & 33.73 & 33.39 & 1.59 & 98.41 \\
French & 181 & 33.53 & 34.09 & 1.85 & 100 \\
Maths & 181 & 34.93 & 35.28 & 0 & 100 \\
As a Whole & & & & & \\
Total score & 347 & 29.91 & 32.33 & 0 & 98.41 \\
French & 347 & 29.99 & 32.91 & 0 & 100 \\
Maths & 347 & 29.43 & 33.87 & 0 & 100 \\
\hline
\end{tabular}

Source: ENSEA, TRECC Survey data.

The households from which working children come are poor both in money and living conditions (Yacouba, 2001). This poverty is characterized, among other things, by the relatively low level of education of the heads of household and poor literacy and numeracy skills. Also, more than $68 \%$ of these households have a monthly income estimated at about 60,000 FCFA (91.5 Euros), equivalent to approximately 1388 FCFA (2.12 Euros) per day. This is accompanied by a monetary poverty rate of $50 \%$ of working children's households.

The proven economic vulnerability of all households further accentuates the phenomenon of child labour and mainly increases the number of children at risk 
of school failure. Overall, the average vulnerability indices indicate that the households under study are economically vulnerable, i.e. they are at risk of well-being.

The majority of young people (14 - 17 years old) are active. In fact, nearly seven (7) out of ten youths have an activity, whether they are young beneficiaries or not. Activities in which young people are mainly engaged are as follows: petty trade, hairdressing, mechanics, welding and agriculture (cf. Table 8).

The majority of women are involved in productive activities, particularly in cash crops such as cocoa, food crops and income-generating activities (IGAs).

However, they have little involvement when it comes to making decisions about cash crops. As a result, they reveal that their level of participation in decision-making on cash crops is low. Moreover, the productive capital of these crops belongs to the head of the household. And they are hardly involved in the allocation of the income generated by these cash crops.

IGAs and food crops are the activities for which the women surveyed seem to have some autonomy. In fact, the majority of them claim to be involved in decision making regarding the production of these activities and their degree of intensity in this decision making is high. Moreover, the productive capital belongs to them and they are heavily involved in decisions regarding the use of the income from these activities.

With regard to the management of household income in general, women are mainly involved only in food expenditure and, to a lesser extent, health and education expenditure. They are very little involved in decisions on savings and investment.

The situation is generally similar for both beneficiaries and non-beneficiaries with respect to decision making on the production and use of income. However, there is a significant difference between beneficiaries and non-beneficiaries regarding leadership within organizations. For example, beneficiaries are more likely to hold positions of responsibility compared to non-beneficiaries.

Not all the components of the WEAI empowerment index could be used since the beneficiaries are drawn from households with an adult male. Thus, only the first component is used and the empowerment score is 0.63 and there is no significant difference between beneficiaries and non-beneficiaries (see Table 9).

Table 8. Status in youth work.

\begin{tabular}{cccc}
\hline & Beneficiary & Non Beneficiary & As a Whole \\
\hline Employed/wage-earner & 7.69 & 27.27 & 20.00 \\
Own account worker & 0.00 & 22.73 & 14.29 \\
Family caregiver (unpaid) & 69.23 & 45.45 & 54.29 \\
Apprentice/Trainee & 23.08 & 4.55 & 11.43 \\
Total & 100.00 & 100.00 & 100.00 \\
\hline
\end{tabular}

Source: ENSEA, TRECC Survey data. 
Table 9. Main WEAI indicators by status.

\begin{tabular}{llll}
\hline Indicators & Beneficiary & Non Beneficiary & As a Whole \\
\hline 5DE (1-M0) & 0.67 & 0.65 & 0.63 \\
Disempowerment score (1-5DE) & 0.33 & 0.37 & 0.36 \\
$\mathrm{~N}$ ( $\mathrm{N}^{\bullet}$ Obs.) & 210 & 232 & 541 \\
\% of autonomous women (1-H) & 0.4 & 0.4 & 41.35 \\
\% of disempowered women (H) & 0.6 & 0.6 & 58.64 \\
$\begin{array}{l}\text { Average Empowerment Scores 5DE } \\
\text { for disempowered women (1-A) }\end{array}$ & 0.44 & 0.38 & 0.35 \\
$\begin{array}{l}\text { Average Disempowerment Scores 1-5DE } \\
\text { for autonomous women (A) }\end{array}$ & 0.55 & 0.62 & 0.64 \\
\hline
\end{tabular}

Source: ENSEA, TRECC Survey data.

\section{Conclusion}

Cocoa is one of Côte d'Ivoire's main export crops and an important source of currency and income for the country and for all stakeholders, especially the producing communities. Cocoa cultivation in Côte d'Ivoire is carried out by multiple farmers under the micro-farming model. Ensuring the sustainability of cocoa implies improving the entire value chain but above all improving the social and living conditions of the producing communities. It is in this context that the major groups of the cocoa sector in Côte d'Ivoire are involved through the implementation of sustainable development projects in the areas concerned.

This paper aims to estimate the basic situation of the communities receiving support in the various cocoa loops in Côte d'Ivoire from East to West. Survey techniques with intervention control groups were implemented. The situation of the communities in terms of monetary and non-monetary poverty is similar to the national situation. At least 4 out of 10 households in these communities are poor, which suggests that cocoa farming is not a factor in escaping poverty. With regard to French and Mathematical skills, the level of children's skills is relatively average and the level of women's skills is low. The situation of women empowerment is no better; only $41 \%$ of women were observed to be autonomous in an average of 6 out of 10 dimensions. Young people are in general (around 70\%) economically engaged mostly in activities as family caregivers (more than 50\%). Approximately only $20 \%$ are self-employed.

These planned interventions in cocoa-producing communities are thus a hope for improving living conditions for sustainable cocoa production. Beyond these reinforcements, an improvement in the transport infrastructure and connectivity of these areas and communities is more than necessary for the improvement of living conditions.

\section{Acknowledgements}

This study was conducted by ENSEA with the support of a grant from TRECC Program in Côte d'Ivoire. The author sincerely thanks the team of the Program 
and all participants in this study. A special thank goes to colleagues who devoted time and their expertise on the project. The author would like to thank anonymous reviewers for their comments and suggestions. The author is also grateful to participants of for research seminar of ENSEA for their valuable's comments on an earlier version of the manuscript.

\section{Conflicts of Interest}

The author declares no conflicts of interest regarding the publication of this paper.

\section{References}

AfDB (2015). Africa Gender Equality Index 2015. Abidjan: African Development Bank Report.

Alkire, S., \& Foster, J. (2007). Counting and Multidimensional Poverty Measurement. OPHI Working Paper 7, Oxford: Oxford University.

Alkire, S., \& Foster, J. (2011). Counting and Multidimensional Poverty Measurement. Journal of Public Economics, 95, 476-487. https://doi.org/10.1016/j.jpubeco.2010.11.006

Alkire, S., Foster, J. E., Seth, S., Santos, M. E., Roche, J. M., \& Ballon, P. (2015). Multidimensional Poverty Measurement and Analysis (cha. 5). Oxford: Oxford University Press. https://doi.org/10.1093/acprof:oso/9780199689491.001.0001

Anderson, M. B. (1988). Improving Access to Schooling in Third World: A Review (Bridge Research Report Series No. 1). Cambridge, MA: Harvard University.

Aos, S., Lieb, R., Mayfield, J., Miller, M., \& Pennucci, A. (2004). Benefits and Costs of Prevention and Early Intervention Programs for Youth. Olympia, WA: Washington State Institute for Public Policy. https://doi.org/10.1037/e602182007-001

Babo, A. (2010). Conflits Fonciers, Ethnicité Politique et Guerre en Côte d'Ivoire. Alternatives Sud, 17, 95-118.

Banque Mondiale (2011). Le système éducatif de la Côte d'Ivoire-Comprendre les forces et les faiblesses du système pour identifier les bases d'une politique nouvelle et ambitieuse. Washington DC.

Bitty, E. A., Bi, S. G., Bene, J.-C. K., Kouassi, P. K., \& McGraw, W. S. (2015). Cocoa Farming and Primate Extirpation inside Cote D'Ivoire's Protected Areas. Tropical Conservation Science, 8, 95-113. https://doi.org/10.1177/194008291500800110

Bros, C., Desdoigts, A., \& Kouadio, H. (2019). Land Tenure Insecurity as an Investment Incentive: The Case of Migrant Cocoa Farmers and Settlers in Ivory Coast. Journal of African Economies, 28, 147-175. https://doi.org/10.1093/jae/ejy019

Cronbach, L. J. (1951). Coefficient Alpha and the Internal Structure of Tests. Psychometrika, 16, 297-334. https://doi.org/10.1007/BF02310555

Dickes, P., Tournois, J., Flieller, A., \& Kop, J. L. (1994). La psychométrie: Théories et méthodes de la mesure en psychologie. Paris: PUF.

Feed the Future (2017). Women Empowerment in Agriculture Index. Brief Note.

Gouvernement de Côte d'Ivoire, Unicef, \& Unesco (2016). Rapport d'Etat du système éducatif national de la Côte d'Ivoire, Pour une politique plus inclusive et plus efficace.

Hütz-Adams, F., Huber, C., Knoke, I., Morazan, P., \& Murlebach, M. (2016). Strengthening the Competitiveness of Cocoa Production and Improving the Income of Cocoa 
Producers in West and Central Africa (p. 156). Bonn: Sudwind eV.

ICCO (2017). Cocoa Bean Production, Grindings and Stocks. Cocoa Year 2016/2017. ICCO Quarterly Bulletin of Cocoa Statistics, Vol. 4, XI.I III (2).

Ingram, V., van Rijn, F., Waarts, Y., Dekkers, M., de Vos, B., Koster, T., Tanoh, R., \& Galo, A. (2017). Towards Sustainable Cocoa in Côte d'Ivoire. The Impacts and Contribution of UTZ Certification Combined with Services Provided by Companies (140 p.). Report 2018-041, Wageningen: Wageningen Economic Research. https://doi.org/10.18174/450223

Ingram, V., Waarts, Y., \& van Rijn, F. (2018). Cocoa Sustainability Initiatives: The Impacts of Cocoa Sustainability Initiatives in West Africa. In P. Umaharan (Ed.), Achieving Sustainable Cultivation of Cocoa (pp. 515-540). Sawston: Burleigh Dodds Scientific Publishing. https://doi.org/10.19103/AS.2017.0021.31

Ingram, V., Waarts, Y., Ge, L., van Vugt, S., Wegner, L., Puister-Jansen, L., Ruf, F., \& Tanoh, R. (2014). The IDH Cocoa Productivity and Quality Programme (CPQP) in Côte d'Ivoire: Impact Assessment Framework and Baseline (p. 198). Den Haag: LEI Wageningen UR.

International Cocoa Inititative (2017). Education and Child Labour Risk for Older Children in Côte D'ivoire.

Kouadio, H., \& Desdoigts, A. (2012). Déforestation, migrations, saturation et réformes foncières: La Côte d'Ivoire entre résilience rurale et litiges fonciers. MPRA Paper 49938, Munich: University Library of Munich.

Matissek, R., Reinecke, J., Von Hagen, O., \& Manning, S. (2012). Sustainability in the Cocoa Sector-Review, Challenges and Approaches. Moderne Ernaehrung Heute, Official Journal of the Food Chemistry Institute of the Association of the German Confectionery Industry, 1-27.

Ministère de l'Éducation Nationale (2014a). L'évaluation du rendement scolaire en mathématiques au CP2, CE2 et CM2. Direction de la Veille et du Suivi des Programmes.

Ministère de l'Éducation Nationale (2014b). Niveau de maîtrise de la lecture des élèves de première année de l'enseignement primaire en Côte d'Ivoire. Direction de la Veille et du Suivi des Programmes.

Ministère de l'Éducation Nationale (2014c). Rapport d'analyse statistique 2013-2014. Direction de la Planification, de l'Évaluation et des Statistiques, Sous-Direction des Statistiques et de l'Évaluation.

Muilerman, S., \& Vellema, S. (2017). Scaling Service Delivery in a Failed State: Cocoa Small-Holders, Farmer Field Schools, Persistent Bureaucrats and Institutional Work in Côte d'Ivoire. International Journal of Agricultural Sustainability, 15, 83-98. https://doi.org/10.1080/14735903.2016.1246274

Nkamleu, G. B., Nyemeck, J., \& Gockowski, J. (2010). Technology Gap and Efficiency in Cocoa Production in West and Central Africa: Implications for Cocoa Sector Development. Abidjan: African Development Bank.

OPHI (2012). Women Empowerment in Agriculture Index. Brief Note.

PASEC (2016). PASEC2014-Performances du système éducatif ivoirien: Compétences et facteurs de réussite au primaire. Dakar: PASEC, Confemen.

Ruf, F., \& Siswoputranto, P. (1995). Cocoa Cycles: The Economics of Cocoa Supply. Cambridge: Woodhead Publishing.

Sen, G., \& Batliwala, S. (2000). Empowering Women for Reproductive Rights. In H. Presser, \& G. Sen (Eds.), Women's Empowerment and Demographic Processes (pp 15-16). New York: Oxford University Press. 
Verter, N. (2016). Cocoa Export Performance in the World's Largest Producer. Bulgarian Journal of Agricultural Science, 22, 713-721.

Wilson, S., Vigneri, M., Serra, R., \& Cardenas, A. L. (2016). Researching the Impact of Increased Cocoa Yields on the Labour Market and Child Labour Risk in Ghana and Côte d'Ivoire. Chatelaine: International Cocoa Initiative (ICI).

Yacouba, D. (2001). Les déterminants du travail des enfants en Côte d'Ivoire. Documents de travail, Groupe d'Economie du Développement de l'Université Montesquieu Bordeaux IV. 


\section{Annex: Method of Calculating the Indicators}

\section{Cronbach Indicator}

Let us assume that,

$$
\delta_{i j}=\left\{\begin{array}{c}
1 \text { if individual } i \text { gives the right answer to question } j \\
0 \text { si if individual } i \text { gives a wrong answer to question } j
\end{array}\right.
$$

Then the proportion of right answer to question $j$ is given:

$$
P_{j}=\frac{\sum_{i=1}^{n} \delta_{i j}}{n}
$$

And an individual's score on a set of questions in one dimension (French or mathematical) is given by:

$$
S C_{i}=\frac{\sum_{i * j=1}^{J} \delta_{i j}}{J}
$$

The list of variables considered is that of the "reading/writing ability" questionnaires.

\section{Poverty Indicators}

Let us assume that,

$$
\delta_{i}=\left\{\begin{array}{l}
1 \text { if } i \text { has a per capita expenditure below the poverty line } \\
0 \text { otherwise }
\end{array}\right.
$$

Then the poverty rate is given by:

$$
P=\frac{\sum_{i=1}^{n} \delta_{i}}{n}
$$

The non-monetary approach aims to measure the households living conditions. The approach used in this study is that of Alkire and Foster (2007, 2011). It is based on the calculation of a Multidimensional Poverty Indicator (MPI). The MPI is made up of ten indicators divided into three basic dimensions: education, health and living conditions. The indicators necessary for its calculation are as follows:

The calculation of this index is done by collecting information from the household survey. Indeed, the socio-demographic characteristics of the individuals and the household make it possible to calculate the indicators of the education and living conditions dimension. Information on mortality and nutrition is needed for the health dimension. However, the nutrition dimension was not taken into account in this study, which could lead to a slight overestimation of household living conditions.

\section{Empowerment Indicator}

Empowerment is the enhancement of people's capacities to make strategic life choices within their households and communities, especially in contexts where this capacity has been limited. Empowerment is measured by an A-WEAI index (IFPRI). This index was launched in 2012 and developed by USAID, the Interna- 
tional Food Policy Research Institute (IFPRI) and the Oxford Poverty and Human Development Initiative (OPHI). It is based on the same principle as the MPI (Multidimensional Poverty Index) with some specificities. Unlike the MPI, it has two components, one of which is a parity index. Its multidimensional nature and its suitability for the rural world justify its choice. The components are designed to be adapted according to the country and cultures.

Five (05) dimensions of agricultural empowerment are selected: Production (women's role in household decision-making regarding production), resources (women's access to productive capital), household control over income, women's individual leadership and influence in the community, and time allocation for women.

Each of these areas is associated with indicators and weights according to their importance. These indicators make it possible to identify areas in which women are not empowered in order to guide national programmes and policies. The following table further illustrates the weights used.

\section{Decision Criterion for Women's Empowerment}

Once the indicator is calculated at the individual level, a threshold must be set to identify "autonomous" women. The criterion is determined from the cumulative weight assigned to each of the indicators. Thus, an individual who has achieved an adequacy of more than $80 \%$ in the weighted factors is said to be Autonomous (cf. WEAI methodology). Normally, the WEAI has two components: the 5DE and a gender parity index (GPI). In this study, it is assumed that the man is par excellence the head of the family and enjoys natural and cultural autonomy, especially in rural areas. It is therefore appropriate to focus on women's empowerment by having the man's views on the involvement of this empowerment in his household. This choice is also partly justified by budgetary constraints. 